REVISTA de

PEDAGOGIE

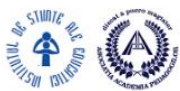

JOURNAL of

PEDAGOGY

http://revped.ise.ro

Print ISSN 0034-8678; Online ISSN: 2559 - 639X

\title{
SOCIAL AND EMOTIONAL LEARNING IN CLASSROOMS. COUNSELLING IN SCHOOL TO AVOID CONFLICTS
}

ÎNVĂTARE SOCIALĂ ŞI EMOŢIONALĂ ÎN SALA DE CLASĂ. CONSILIERE ÎN ŞCOALĂ PENTRU A EVITA CONFLICTELE

\section{Karin SONNLEITNER}

\author{
Journal of Pedagogy, 2021 (2), 41 - 57 \\ https://doi.org/10.26755/RevPed/2021.2/41
}

The online version of this article can be found at: https://revped.ise.ro/en/rp-2021-2/

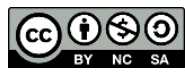

This work is licensed under the Creative Commons Attribution-NonCommercial-ShareAlike 4.0 International License.

To view a copy of this license, visit http://creativecommons.org/licenses/by-nc-sa/4.0/ or send a letter to Creative Commons, PO Box 1866, Mountain View, CA 94042, USA

Published by:

Centrul Național de Politici și Evaluare în Educație

UNITATEA DE CERCETARE ÎN EDUCAȚIE

https://www.ise.ro/

https://rocnee.eu/

Further information about Revista de Pedagogie - Journal of Pedagogy can be found at:

Editorial Policy: http://revped.ise.ro/editorial-policy/

Author Guidelines: http://revped.ise.ro/en/author-guidelines/ 


\title{
SOCIAL AND EMOTIONAL LEARNING IN CLASSROOMS. COUNSELLING IN SCHOOL TO AVOID CONFLICTS
}

Karin Sonnleitner*

University of Graz,

Center for Social Competence and Institute of the Foundations of Law,

Graz, Austria

karin.sonnleitner@uni-graz.at

\begin{abstract}
Heyse \& Erpenbeck (2009) define counselling competence very broadly as the ability to counsel people and organisations. This requires for teachers an extensive knowledge of content, social-emotional competence and solution-oriented thinking. In this context, the article focuses on the one hand on the location of the legal basis for teacher training in higher education in the context of counselling competence and how counselling skills can be improved to avoid conflicts in the classroom. On the other hand it describes the handling and use of counselling skills in everyday school life based on the results of focus group discussions within the Erasmus+ project SEEVAL.
\end{abstract}

Keywords: conflicts in school, content analysis, counselling, focus groups, social emotional learning.

\section{Rezumat}

Heyse şi Erpenbeck (2009) definesc competen a de consiliere într-un mod foarte larg ca fiind capacitatea de a consilia persoane şi organiza ii. Aceasta solicită din partea profesorilor cunoştin e extinse de con inut, competen e socioemo ionale şi o gândire orientată pe solu ii. In acest cadru, articolul se concentrează pe de o parte pe identificarea bazei legale privitoare la formarea

* Senior Lecturer, Center for Social Competence and Institute of the Foundations of Law, University of Graz, Graz, Austria. 
profesorilor în învă ământul superior, în ceea ce priveşte competen a de consiliere. Pe de altă parte, articolul descrie utilizarea competen elor de consiliere $\hat{\imath} n$ via a şcolară curentă, cu referire la rezultatele discu iilor din cadrul focus-grupului realizat in proiectul Erasmus + SEEVAL.

Cuvinte-cheie: analiză de con inut, conflicte în şcoală, consiliere, focus grup, învă are socio-emo ională.

\section{Introduction}

Since counselling is broadly defined as the ability to counsel people and organisations (Heyse \& Erpenbeck, 2009), counsellors and teachers alike need an extensive knowledge of content, social emotional competence and solution oriented thinking. Due to social changes, growing complexity and the loss of reliable structures, the need for counselling in schools is increasing. Consequently, teachers not only counsel pupils, but also need guidance themselves in order to cope with the diverse tasks. In this context, the following questions arise: how they deal with conflict situations in the classroom and what changes are needed to enable a better implementation of social and emotional learning in school.

The education of teachers for primary and secondary education has been fundamentally reformed in the recent years in Austria. The most visible innovation is the introduction of a four-year bachelor's degree programme, followed by a master's programme lasting at least one or two years. There are four network regions between universities/colleges for teacher education in Austria. The Austrian Federal Framework Law on the Introduction of a New Education for Pedagogues, which was enacted in 2013, stipulates in $\S$ 42 (1a) that the curricula of bachelor's and master's degree programmes for obtaining a teaching profession must be competence-based and include the teaching of general and special pedagogical competences, subject-specific and didactic competences, inclusive and intercultural competences, social competences, counselling competences and professional understanding. In the now applicable paragraph, different competences are still implemented in the curricula.

In this context, it is worthwhile to clarify: the meaning of counselling 
competencies for conflict management in the context of social emotional learning; then how social and emotional learning be integrated in school, which methods to use and what changes to plan for. Finally, two practical tools are provided for teachers to use directly in the classroom.

\section{Improving counselling competences to avoid conflicts}

In everyday school life, the teaching staff must act in a counselling capacity at various levels, for example in parental work, with other teachers and school children (Drechsel et al., 2020; Gartmeier, 2019). The focus will be on the classroom with all its conflicts, where teachers should convey security, show professional competence and signal empathy in order to impart social emotional learning to the students (Grewe, 2015; Palzkill et al., 2015; Schnebel, 2017). Social emotional learning is a process in which children and adults acquire and effectively apply the knowledge, attitudes and competencies to understand and manage emotions, set and achieve positive goals, feel and show empathy for others, build and maintain positive relationships and make responsible decisions. So, there are lots of aspects, which teachers have to observe. The five areas - self-awareness, self-management, social awareness, relationship skills and responsible decision-making - are fundamental to social emotional learning (CASEL, 2017).

All areas are important to diagnose and solve conflicts. Conflicts often have negative connotations, yet they hold great potential. Aconstructive approach to conflicts leads to further developments in the classroom. To achieve this progress, however, a systematic approach to the topic is necessary (Sonnleitner \& Gschweitl, 2021). Lessons, in which social emotional learning takes place are suitable to teach pupils different ways to systematically and constructively analyse, diagnose, manage and solve conflicts.

\section{Method}

Building on this theoretical background, focus group discussions were conducted within the framework of the international project SEEVAL (Social and Emotional Education - Building Inclusive Schools and Ownerships of 
Values). A focus group is "a carefully planned discussion designed to obtain perceptions on a defined area of interest in a permissive, nonthreatening environment" (Krueger \& Casey, 2009, p. 2). With this kind of qualitative research, the outcomes are in-depth information about the daily problems and challenges (Danner et al., 2018). Multiple participants explain their own standpoint in a simultaneous discussion so that the outcome is - in the best case - a broad range of issues and more than the outcome of an individual interview with a single participant (Cyr, 2019). The number of participants depends on the purpose and the goal (Vaughn et al., 1996). At the beginning of the focus group, an opening question is asked to get the discussion going. Questions aiming at factual information are a good choice. This is followed by introductory and transitional questions that introduce the topic. Key questions are at the centre of the discussion and address the actual research questions. Concluding questions summarise and give the facilitator reassurance that he/ she has understood the participants well (Schulz et al., 2012).

The purpose of the SEEVAL-study is to set up a training programme to develop the educators' social and emotional competences for the classroom learning. For this purpose, best practices and methods from Europe will be collected and guidelines will be developed. In the three focus groups we collected and analysed information about needs and perceptions on social and emotional learning in schools.

WUS Austria (2021) and the Center for Social Competence (2021) at the Graz University invited teachers and school psychologists working with children aged 12 to 18 as well as teachers from universities and university colleges for teacher education.

Among the participants of all three focus groups were schoolteachers (13) and school psychologists (2) as well as teacher trainers from universities (1) and university colleges for teacher education (5). The focus group discussions lasted between 80 and 90 minutes each. Experience in social emotional learning was a precondition for participation.

The focus groups were recorded, transcribed and finally paraphrased following the qualitative content analysis of Mayring (2015). All responses remain anonymous. 
The following chapters contain the results of the content analysis.

\section{Results}

To reach the purpose we asked the 21 persons the following questions:

1. How is social and emotional learning integrated in their school and what does teaching look like?

2. What specific practices, methods, books, materials are used?

3. What changes are needed to enable a better implementation of social and emotional learning in school?

\subsection{Integration of social emotional learning in school}

The interview partners were asked how social and emotional learning is integrated in their school and what does teaching look like?

In the majority of schools one hour a week, mostly in the first hour on Monday, the children have the opportunity to strengthen their interaction with each other, to observe themselves, to exchange ideas and to work on conflicts in the social emotional learning lesson. Besides, in three schools social and emotional learning is even part of the school mission statement and has been institutionalized as a subject, which has an effect outside of the lesson provided for it. If necessary, this lesson can be extended to the following second lesson.

But the curriculum is in the foreground and the teachers would like to have more time to bring in social aspects. So, one or two hours are too few in view of the large range of topics. The interview partners are sure that social emotional learning lessons are extremely important and meaningful and there are still enough conflicts that take up a lot of time.

The teachers focus on personality development and want to strengthen the individuality and togetherness with for example a strength's portfolio or a class climate conference. Such a conference can be convened by pupils, parents and teachers in case of conflicts, in which conflicts are discussed. 
They also train buddies and peers. The buddies are pupils who accompany new pupils and make it easier for them to get started and arrive at the new school. There is a special training for the peer mediators, in which conflict strategies are learned so that the pupils are able to solve minor conflicts themselves without adult intervention and to support conflict resolution. One teacher describes that in his school the introductory seminar is held by school social workers.

Further trainings include non-verbal and non-violent communication as well as conflict resolution strategies. Moreover, for example, courses in personality development, communication, coaching, social learning, human dignity and human respect are offered at the university. Many teachers name the concept of non-violent communication (NVC), in which the focus is on empathy, self-empathy and on connecting, appreciative communication. NVC is offered as an elective subject for primary and secondary education as well as for vocational education. One opportunity to expand the social and emotional competences are project days.

One teacher points out that social and emotional learning is not only a subject, but also firmly integrated in the regular lessons. It happens every day and really every hour. In the first school year, the focus of social learning is on oneself, getting to know one's own strengths and weaknesses: pupils are strengthened where they can be strengthened. In the second school year, social learning focuses on the group. It is about learning acceptance meaning that everyone is good and okay the way they are. Then, in the third school year, the focus is on teamwork, and in the fourth grade on career orientation. One teacher emphasises that with regard to the topic of social emotional learning in his school there are officially no lessons, no value units, nothing at all. However, if necessary, the head-master agrees to deal with conflicts or problems outside the lesson. Having no lessons is a problem in general. Another teacher mentions a special example: In her school the hour, which is provided for social emotional learning, is split with the subject of computer science. So, the lesson never takes place with the whole class and doesn't make sense, because individual topics often cannot be finished or work processes have to be interrupted or aborted.

In another school a time-out concept is implemented in which the teaching 
staff has the opportunity to send conspicuous children out of class so that a colleague who has developed the concept can talk to the pupil about the conflict. Appropriate documentation and scoring take place. One teacher explains compulsory events in the area of social and personal competence. The students deal with their attitudes and values with regard to various focal points (e.g., multilingualism, migration, human rights education). These events take place within the framework of group coaching.

\subsection{Methods Being Used}

The following question was asked about the category of materials, practices and methods: What specific practices, methods, books, materials on social and emotional learning are used?

No matter which method is used, the main thing is that it is used in an authentic manner. Two teachers express their preference for emotional pattern cards. In one school there exists a method pool to choose from. The teaching staff can choose for themselves what they can work well with, because not everyone is comfortable with everything. The choice of methods should be individually adapted to the class. If someone wants to incorporate social and emotional learning in the classroom, they will definitely do it.

Most of them use methods, which they have acquired through participation in further training. They underline the importance of such a pool of material and mix those methods with classic lesson plans, which give a certain security at the beginning, especially for teachers who are afraid of teaching social and emotional learning. It is important to have room for play, conversation and exercises. There are certain subjects where there is always room and other subjects where it is very difficult. 
Table no. 1. Methods being used

\begin{tabular}{|l|l|l|}
\hline apps & full text documents & role plays \\
\hline change of perspective & group work reflection & slide sets \\
\hline cooperation games & learning games & sports community games \\
\hline countless books & lists of needs and feelings & theatre methods \\
\hline digital media & nonviolent communication & various power point \\
\hline discussions & online materials & working with impulses \\
\hline experiencing silence & paraphrasing & world café \\
\hline
\end{tabular}

They also use meditation exercises to experience silence. Coaching conversations are another method. The conversation always takes place at the end of the semester. Pupils can talk to teachers at eye level, which fosters the relationship level. As another method, one teacher mentions the strengths pass with a focus on strengths work. This is created with the involvement of parents, siblings or other persons who name the students' strengths. The children simply learn to know their strengths, also to know their weaknesses and to learn to talk about themselves. The teachers also recommend various books like "Solving Conflicts Yourself" by Kurt Faller or the Handbook for Human Rights Education by Wolfgang Benedek, the Berlin-Brandenburg "Anti-Bullying Primer" or "Dealing with Conflicts NonViolently" or "Mediation in Schools" by Jamie Walker. Materials from the University of Vienna, the POLIS Centre and materials from Özeps are also used.

Another aspect is the exchange among teachers. Also, the networking between different school systems or systems and organizations are very important. One teacher has exchange meetings with colleagues and a two-day training to increase the pool of materials. One teacher adds the topic of reflection about the method and the way of giving the pupils feedback. What is suitable for the teacher and what for the content? For the feedback you have to ask yourself, what do I see when the pupils play different roles and what is the outcome for real life situations? Self-reflective learning, problem-based learning, an appreciative, empathetic approach and, above all, communication at eye level is encouraged. Another teacher mentions the VIVID (2021) association in the field of addiction prevention. The association has a very 
good, easy-to-implement concept with very concrete suggestions for expanding the social and emotional competence of the pupils. VIVID provides folders for free with suggestions and ideas, especially for teachers whose experience with social learning is still at the beginning. Although VIVID is an addiction prevention programme, the focus is on strengthening one's own personality. It is about making oneself strong and recognizing one's actual abilities.

In a school this folder is still called "I-folder" in the first year. The folder begins with the "I", then expands to include the "you" and ends with the "togetherness". The folder gives teachers the possibility to create a lesson very quickly.

\subsection{Changes}

In the category of changes, the teachers answer the question: What changes are needed to enable a better implementation of social and emotional learning in school?

All participants say that there is a need for changes, e.g. more breaks or more free space, but this is not possible in the current school system. There should be a concept that strengthens the pupils' personal responsibility and independence within the framework of a coaching lesson. Especially social learning needs more time and space in everyday school life. The curriculum should implement that the teachers should work with real life situations, in which pupils learn how to deal with their emotions and react appropriately. Another problem is the structure of a "50-minute cycle" for one subject. Conflicts are often left half-finished. One teacher sees the need for change in society in general, away from the performance principle towards a society in which social and emotional competences gain in value. One teacher sums it up with the sentence that she can create her own place, but it also needs a place from the system. Social and emotional learning needs to be brought more into the public awareness, the value of this area needs to be increased. To strengthen the self-responsibility of the pupils, student parliament, a social course or a chill base or peer mediation can be implemented. In the peer mediation, peers or high school students come to the classes and help the 
pupils to solve their conflicts. This approach is very popular, because the conflict parties feel better understood by their peers. For three teachers the problem lies in the lack of financial and time resources as well as personal competences of the individual teacher. When you have to solve a complex problem or a concrete situation with binary solution options, it needs more than just teaching the subject matter. It needs other approaches and more practical experience. Furthermore, the headmaster makes a significant contribution to whether teaching of social and emotional learning is promoted or rather hindered. If the teacher has a lot of leeway, he/she is able to move and achieve something. As a result, emotional and social learning should already be taught as part of the university training and be deepened or expanded in further training and not firstly acquired. Teachers should be supported with counselling, supervision, stress management, work-life balance, resilience, which are currently not really included in the basic university curriculum. One teacher demands free, continuous offers of supervision or coaching for teachers. Counselling by colleagues and exchange should be encouraged. A way to counsel the pupils to avoid conflicts are break-out rooms, in which new groups of students can always be put together. This also helps to avoid feelings of exclusion and ensures mutual communication. During attendance hours additional community-focused projects are available. The school of one teacher has chosen the vision: "In the first two weeks of school only social learning happens and - how do I learn?". It focuses on the attitude towards oneself and one's learning. Mostly all teachers agree that the role model effect and a positive attitude is important for the pupils. They imitate the behavior.

Picking up on the COVID situation one teacher adds that the initial technical problems were quickly solved, but the lack of the social component became increasingly obvious. According to this, the technical handling of distance learning functions smoothly for the most part, but the students lack the process of interaction, social learning, human exchange or just being able to vent their frustrations with a fellow student.

In the next chapter the practical tools nonviolent communication and paraphrasing, which were named by the participants of the focus groups are described. Both tools can directly be integrated in classrooms. 


\section{Practical tools}

Nonviolent Communication, developed by Marshall Rosenberg $(2003,2015)$ guides us to reframe how we express ourselves, how we hear others and resolve conflicts by focusing our consciousness on what we are observing, feeling, needing, and requesting. Through these four steps of nonviolent communication, appreciative conversations can be held in order to avoid or resolve conflicts.

The first component of nonviolent communication involves the distinction between observation and evaluation. Through pure observation, you can make your conversation partner more aware of your own situation. If observation and evaluation are mixed up, the other person hears criticism more often and takes a defensive stance. Nonviolent communication does not aim to completely hide evaluations, but to develop an awareness of the separation of these two opposites.

It is useful to imagine how a camera objectively observes a situation from the outside. A camera can also only be used to record observations without giving an assessment. So, an observation is always related to a time frame and a time context (Rosenberg, 2016; Rust, 2011).

Table no. 2. Example for observation and evaluation

\begin{tabular}{|l|l|}
\hline Observation & Evaluation \\
\hline $\begin{array}{l}\text { On Wednesday you went to the cinema } \\
\text { with my girlfriend. }\end{array}$ & $\begin{array}{l}\text { On Wednesday you met with my girlfriend for } \\
\text { quite a long time. }\end{array}$ \\
\hline
\end{tabular}

While in the first phase of nonviolent communication observation is relevant, in the second step special attention must be paid to feelings. In today's society, feelings are often not given special importance and many people also have difficulties in clearly expressing their real feelings. Fear, sadness, but also happiness and joy are often ignored. In this context, Rosenberg (2016, p. 51) emphasizes that the phrase "I feel that" or "I feel as if..." only expresses an opinion, while a feeling itself is not revealed (for example "I 
feel as if I'm living with a wall"). Therefore, the formulation "I am ..." should be used, for example /

I'm exhausted.

I'm happy.

I'm frustrated.

I'm excited (Holler, 2005, p. 64, 74).

Needs are the root of feelings and the elementary conditions for life and survival. Just as feelings often cannot be expressed, needs are also confused with strategies, interpretations and behavioral diagnoses of others. So, conflicts often arise in the family, in everyday school life and everyday work as a result of the inadequate fulfillment of needs.

For expressing needs you can use the following language patterns:

1. I feel ... because I ... need.

E.g.: I feel under pressure because I need rest/relaxation.

2. I am ... because ... is important to me /for me.

E.g.: I am annoyed because it is important to me to use my time wisely.

The expression of needs significantly influences the four steps of nonviolent communication and also affects the others. To resolve a conflict, it is often necessary to ask about one's own needs and those of the other person.

After observation, feelings and needs, the fourth element of non-violent communication is the correct formulation of requests. Requests often contain disguised demands or are formulated vaguely and ambiguously. In order to fulfill a need, requests should be named in such a way that the willingness of the other person to respond considerately increases as well. It should therefore be avoided to express requests in a negative form, rather it is advantageous to use positive language of action. However, conveying a clear and unambiguous request seems difficult, especially since there may be uncertainties about what you actually want yourself. Because of this, a request should contain a specific action, be positively formulated and be verifiable. "Pious wishes" should be avoided and requests that can be fulfilled should be formulated.

Summing up nonviolent communication is not a method to change the behavior 
of other pupils and teachers or to get one's own way. This mediative technique is suitable for building relationships that include sensitive, appreciative and considerate behavior.

Another tool which teachers can integrate to avoid conflicts in classrooms but can also be used in counselling situations is paraphrasing. It is important that not only the teacher paraphrases. He/she should also tell the students the background of this tool so that also the pupils are able to use it. While paraphrasing can be explained very simple, it is harder to paraphrase in (high) escalated situations.

In the sense of nonviolent communication, paraphrasing is also done by reproducing what is heard in one's own words, with the difference of formulating the content as a question. This signals understanding to the interlocutor and, if necessary, provides the opportunity for correction. The aim of the question is to empathize with the other person and at the same time to support him or her in revising what has been misunderstood. Paraphrasing is useful in situations where there is uncertainty about whether you have understood what you have heard correctly or when the other person needs confirmation (Rosenberg, 2016).

This kind of summary helps to sort topics and arguments as well as to check if everything relevant has been named (Lindemann et al., 2018). It gives the speaker the opportunity to reconsider his/her statement. If the statement was understood correctly, the paraphrase is confirmed. Otherwise he/she has the opportunity to correct it (Rosenberg, 2016).

It is therefore a question of the interlocutor reproducing what he or she has heard in his or her own words. Thus, the understanding can be checked and corrected if necessary to prevent misunderstandings. Paraphrasing shows that what was said by the person speaking was both heard and the essence of his statement was grasped by the interlocutor and there is a willingness to continue talking about the topic that has been started. Paraphrasing signals interest and appreciation.

Example 1:

„I feel quite disregarded.” 
„It sounds like you are dissatisfied and disappointed because it's about appreciation." (Holler, 2017, p. 338).

Example 2:

„I don't know how we're going to do this if nobody has the overview and results aren't being matched."

„You are concerned with transparency and exchange. Does that apply?" (Geier, 2017, p. 322).

\section{Discussion}

Regarding the practical application of social emotional learning in schools, it belongs to the interest of the school management and the agreed school mission statement, if teachers use social emotional learning in the classrooms. The headmaster can support the teachers by allowing them to attend additional workshops to develop their competences. Most of the participants of the focus groups report that social emotional learning is integrated selectively into daily school life with one or two lessons per week. Usually, these units take place in the first and second year of secondary education. There are nine years of compulsory education in Austria. For the first four years, pupils must attend primary schools. After graduation, children from the age of 10 choose between different types of secondary school. Then, all pupils must either go into professional training or continue school education, until the age of 18 .

At the beginning of secondary education, some teachers use the first one or two weeks for social emotional learning or an excursion in which the class climate is strengthened and the pupils, who attended different schools, get to know each other.

The teachers mention several topics, which are discussed in social emotional learning classes, for example conflicts in the school class, teamwork, bullying, accepting diversity, personality development and getting to know their own strengths and weaknesses. Pedagogical advisors, school mediators and teachers educate buddies, but in the most cases the individual class teachers have to implement social emotional learning. The most important problem is 
that there is not enough time for this type of learning in the individual subjects.

The participants agree that they gathered a pool of methodologies and tools over the last years. The teachers took part in further education and workshops, gathered materials, and make it available to their colleagues. These materials are literature, handbooks, guidelines ready-made lessons or best practices.

All focus group participants prefer certain methods and tools and use them more often because they feel comfortable using the techniques. Some of the tools are role playing games, theatre methodologies, group work, taking positions in the room, emotion cards, cooperation games or peer mediation.

The teachers suggest including obligatory social emotional learning courses for future teachers at the university level. Moreover, pre-service teachers should have a lot of practical training to gain more experience in the classroom during studying at the university. For all teachers free counselling, coaching and supervision should be available. Some teachers are of the opinion that social emotional learning should be anchored in school development policies. Furthermore, the local authorities for education should regulate it. With a whole-school approach not only committed teachers are able to implement this form of learning. Some teachers mention that changes are sometimes dreams, which can't be realized, because first the school management has to integrate social emotional learning in the professional curriculum.

The results show that young teachers are often unprepared to deal with stress in conflict situations but have lots of professional competences. Therefore, counselling competence is especially important in situations where social emotional learning (e.g., teaching conflict management competences) is required. This has on the one hand a positive impact on the individual child, and on the other hand on the general atmosphere in the classroom. More time and more space for dealing with conflicts and other daily challenges, such as strengthening the classroom climate, should be deeply embedded in the school culture. In addition, networking opportunities between teachers, including those from different school systems, should be considered to share practical experiences and provide space for personal exchange (WUS Austria, 2021). 


\section{References}

- CASEL (Collaborative for Academic, Social, and Emotional Learning). (2021, September 6). What Is the CASEL Framework? https://casel.org/sel-framework/

- Center for Social Competence. (2021, September 6). https://soziale-kompetenz.uni-graz.at/de/

- Cyr, J. (2019). Focus Groups for the Social Science Researcher. Cambridge University Press.

- EV South-East. (2021, September 6). https://www.lehramt-so.at/ev-sued-ost/

- Danner, M.J.E., Worth Pickering, J., \& Paredes, T.M. (2018). Using focus groups to listen, learn, and lead in higher education. Stylus Publishing, LLC.

- Drechsel, B., Sauer, D., Paetsch, J., Fricke, J., \& Wolstein, J. (2020). Beratungskompetenzen von Lehramtsstudierenden im erziehungswissenschaftlichen Studium evidenzbasiert fördern - Das Bamberger PeerBeratungstraining. Sonderheft Evidenzbasierung in der Lehrkräftebildung, EZFE, 4, 193-214.

- Gartmeier, M. (2019). Elternberatung als Herausforderung: Eine Perspektivenübernahme. Pädagogische Führung. Zeitschrift für Schulleitung und Schulberatung, 6, 212-213.

- Geier, F. (2017). Kommunikation in der Mediation. In Th. Trenczek, D. Berning, C. Lenz \& H.-D. Will (Eds.), Handbuch Mediation und Konfliktmanagement (2nd ed., pp. 316-322). Nomos.

- Grewe, N. (2015). Gesprächsführung und Leitlinien der Beratung. In N. Grewe (Ed.), Praxishandbuch Beratung in der Schule: Grundlagen, Methoden und Fallbeispiele (3rd ed.). Link.

- Heyse, V., \& Erpenbeck, J. (2009). Kompetenztraining: Informations- und Trainingsprogramme (2nd ed.). Schäffer-Poeschel.

- Holler, I. (2005). Trainingsbuch Gewaltfreie Kommunikation. Junfermann Verlag.

- Holler, I. (2017). Gewaltfreie Kommunikation in der Mediation. In Th. Trenczek, D. Berning, C. Lenz \& H.-D. Will (Eds.), Handbuch Mediation und Konfliktmanagement (2nd ed., pp. 335-339). Nomos.

- Krueger, R.A., \& Casey, M.A. (2009). Focus groups: A practical guide for applied research (4th ed.). Sage.

- Lindemann, H., Mayer, C.-H., \& Osterfeld, I. (2018). Systemisch-lösungsorientierte Mediation und Konfliktklärung. Vandenhoeck \& Ruprecht GmbH \& Co. KG.

- Mayring, Ph. (2015). Qualitative Inhaltsanalyse: Grundlagen und Techniken (12th ed.). Beltz.

- Palzkill, B., Müller, G., \& Schute, E. (2015). Erfolgreiche Gesprächsführung in der Schule: Grenzen ziehen, Konflikte lösen, beraten. Cornelsen.

- Rosenberg, M. (2003). Life-Enriching Education: Nonviolent Communication 
helps schools improve performance, reduce conflict, and enhance relationships. PuddleDancer Press.

- Rosenberg, M. (2015). Nonviolent Communication: A Language of Life (3rd ed.). PuddleDancer Press.

- Rosenberg, M. (2016). Gewaltfreie Kommunikation. Eine Sprache des Lebens (12th ed.). Junfermann Verlag.

- Rust, S. (2011). Wenn die Giraffe mit dem Wolf tanzt. Vier Schritte zu einer einfühlsamen Kommunikation (8th ed.). KOHA-Verlag.

- Schnebel, S. (2017). Professionell beraten: Beratungskompetenz in der Schule (3rd ed.). Beltz.

- Schulz, M., Mack, B., \& Renn, O. (Eds.). (2012). Fokusgruppen in der Empirischen Sozialwissenschaft: Von der Konzeption bis zur Auswertung. VS Verlag für Sozialwissenschaften.

- Sonnleitner, K., \& Gschweitl, V. (2021, September 6). Conflict Diagnosis: How to deal with a conflict?

http://skills.turiba.lv/files/ARTICLE\%20Conflict\%20Diagnosis.pdf

- Vaughn, Sh., Schumm, J., \& Sinagub, J. (1996). Focus Group Interviews in Education and Psychology. Sage Publications.

- VIVID. (2021, September 6). https://www.vivid.at/

- WUS Austria. (2021, September 6). Austrian National Report on social and emotional learning. http://www.wus-austria.org/files/user/docs/Projects/ SEEVAL/Report_Focus-groups_Round-tables_Austria_FINAL.pdf

- WUS Austria. (2021, September 6). https://www.wus-austria.org/

The online version of this article can be found at: http://revped.ise.ro/category/2021-en/

\section{(Cc) BY-NC-BA}

This work is licensed under the Creative Commons Attribution-NonCommercial-ShareAlike 4.0 International License.

To view a copy of this license, visit http://creativecommons.org/licenses/by-nc-sa/4.0/ or send a letter to Creative Commons, PO Box 1866, Mountain View, CA 94042, USA.
Versiunea online a acestui articol poate fi găsită la: http://revped.ise.ro/category/2021-ro/

\section{(cc) $\mathrm{Br}-\mathrm{NC}-\mathrm{sa}$}

Această lucrare este licen iată sub Creative Commons Attribution-NonCommercial-ShareAlike 4.0 International License.

Pentru a vedea o copie a acestei licen e, vizita $i$ http://creativecommons.org/licenses/by-nc-sa/4.0/ sau trimite i o scrisoare către Creative Commons, PO Box 1866, Mountain View, CA 94042, SUA. 